\title{
Regional Mining of Zeolite, Current Mining Management and Quality Perspective by 2050
}

\author{
Slavomír Drevko ${ }^{1, *}$, Mária Drevková ${ }^{1}$, and Martina Vasilková Kmecová ${ }^{1}$ \\ ${ }^{1}$ Technical University of Kosice, Faculty of Mining, Ecology, Process Control and Geotechnologies, \\ Letná 9, 04200 Kosice, Slovak republic
}

\begin{abstract}
The submitted contribution describes the regional extraction of the natural zeolite around Vranov nad Topl'ou (Košice' region). Zeolite is mined here for quarries Nižný Hrabovec, Majerovce, Kučín and Pusté Čemerné. The zeolite is mined by private companies and processed into different fractions (according to requirements and application areas of use in the economy). There is a degree of air, soil and ground water pollution around the quarries. In the contribution attention is paid not only to pollution as such but also to the overall state of the landscape load, level of remediation and reclamation. Mining and treatment of extracted material requires certain measures to protect and preserve the surrounding natural environment. Post therefore also refers to the level of pollution and damage to the country and the prospects for its sustainability until 2050 .
\end{abstract}

\section{Introduction}

Natural zeolite is used in the different areas thanks to its specific physical and chemical properties resulting from its unique crystalline structure (agriculture, industry, ecology, building industry, household products). The Slovak Republic is one of the five most important zeolite producers in the world. Around $117 \mathrm{kt}$ is mined annually, which represents a higher production than the USA $(64 \mathrm{kt})$ or Turkey $(50 \mathrm{kt})$. World production of zeolite is estimated at 2,7 to 3,2 Mt a year. There are 7 registered zeolite deposits on the territory of the Slovak Republic, of which 6 are located in the east of Slovakia in the mining region, which is devoted to this entire contribution.

Zeolite mining mainly causes air pollution. The quarries for zeolite mining are located in the cadastre of municipalities, so the emphasis on minimizing the harmful effects of mining is very high. Current mining management is concerned with the implementation of the Operational Programme Environmental 2007-2013. This concept has created the baseline for the Operational Programme Environmental Quality 2014-2020.

\footnotetext{
* Corresponding author: maria.drevkova@,tuke.sk
} 


\subsection{Košice' mining region - district Vranov nad Topl'ou}

The Košice mining region - the district of Vranov nad Topl'ou is located in the eastern part of eastern Slovakia (part of the region significantly affects the Prešov region). In this area there are 6 of 7 registered zeolite deposits in Slovakia [2], [5].

\subsection{Description of quarries}

Quarry Kučín: Kučín zeolite is macroscopically a compact light-greenish coloured rock having conchoidal fracture. Desiccated crude product shows grey-greenish colour. Mineralogical composition is $82-84 \%$ of clinoptilolite. Clinoptiolite, a member of the zeolite mineral group forms a utility substance and is uniformly disseminated within the rock deposit in Kučín, to the highest quality of this type in the world. Calculated and approved geological reserves of the claimed Kučín zeolite deposit show 2382000 t. Both the deposit and mining area are located $300 \mathrm{~m}$. south-eastward from Kučín village belonging to Vranov nad Toplou district. From geological point of view, the zeolitic tuffs zone between Kučín and Pusté Čemerné villages forms a uniform entity. The deposit has been created by zeolitization of ash rhyodacite tuffs deposited in water (marine) environment. The deposit is monolithic. A large complex of the Early Badenian Hrabovec tuffs is the result of the only volcano sedimentary process, which hasn't been interrupted by any other specific sedimentation [1], [8].

Quarry Nižný Hrabovec : During the development of the earth, nature has left us a precious gift - zeolite (clinoptilolite). It is a natural mineral with exceptional physical properties resulting from its special crystal structure. One of the best deposits of clinoptilolite in the world and careful processing method allows us to offer cuttingedge products. Company here has the permision for mining, quarrying and preparation of mineral deposits by superficial manner in quarries and for the treatment and processing of minerals, carried out in connection with their extraction. Mining company has its own high-quality natural zeolite deposits in the designated mining areas of Nižný Hrabovec [1], [2].

Quarry Majerovce and Pusté Čemerné : The zeolite extracted on the Majerovce and Pusté Čemerné is its quality and structure the same as the zeolite from the Kučín deposit. The quality of zeolite extraction in these fractures is also the same [2].

\subsection{Reserves and production of zeolite deposits}

Demand for zeolites is covered by domestic production in Slovakia, shown in Table 1. Data on imports and exports are not available [1], [8].

Table 1. Reserves and production of zeolite in SR (2010-2015) [1].

\begin{tabular}{|c|c|c|c|c|c|c|}
\hline Year & $\mathbf{2 0 1 0}$ & $\mathbf{2 0 1 1}$ & $\mathbf{2 0 1 2}$ & $\mathbf{2 0 1 3}$ & $\mathbf{2 0 1 4}$ & $\mathbf{2 0 1 5}$ \\
\hline Number of deposits & 6 & 6 & 6 & 6 & 7 & 6 \\
\hline -exploited & 3 & 3 & 3 & 3 & 3 & 4 \\
\hline Reserves (kt) & 113215 & 119582 & 119475 & 119659 & 197602 & 197460 \\
\hline Mine production (kt) & 97 & 103 & 105 & 115 & 117 & 142 \\
\hline
\end{tabular}




\subsection{Mining companies and share of mine production}

The mining companies in the zeolite quarries in this region belong SLOVZEOLIT s.r.o., VSK PRO-ZEO s.r.o. and ZEOCEM, a.s.. Their share in the exploration and production of zeolite is different, shown in Fig. 1.

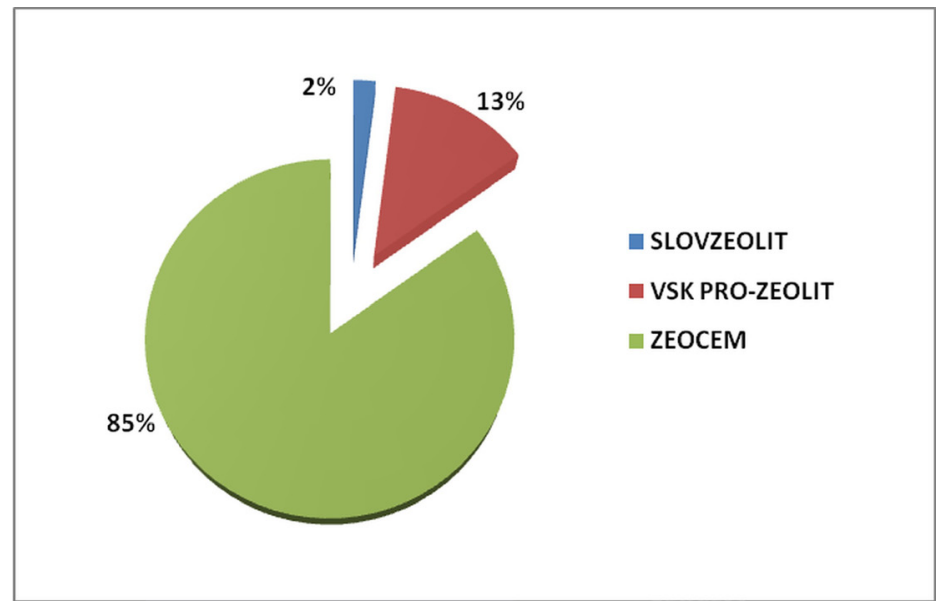

Fig. 1. Mine production share [1].

\section{Air quality management area}

Air quality management areas are identified and determined to the results of air pollution assessment in the Slovak republic. Legal basic is the At No. 137/2010 Coll. On air protection (Article 9-2, 3). On the SR map, shown in Fig. 2, the selected region (Vranov nad Toplou) can be seen as an area that is monitored for air pollution level. This area is included among the delineated air quality management areas [2], [9].

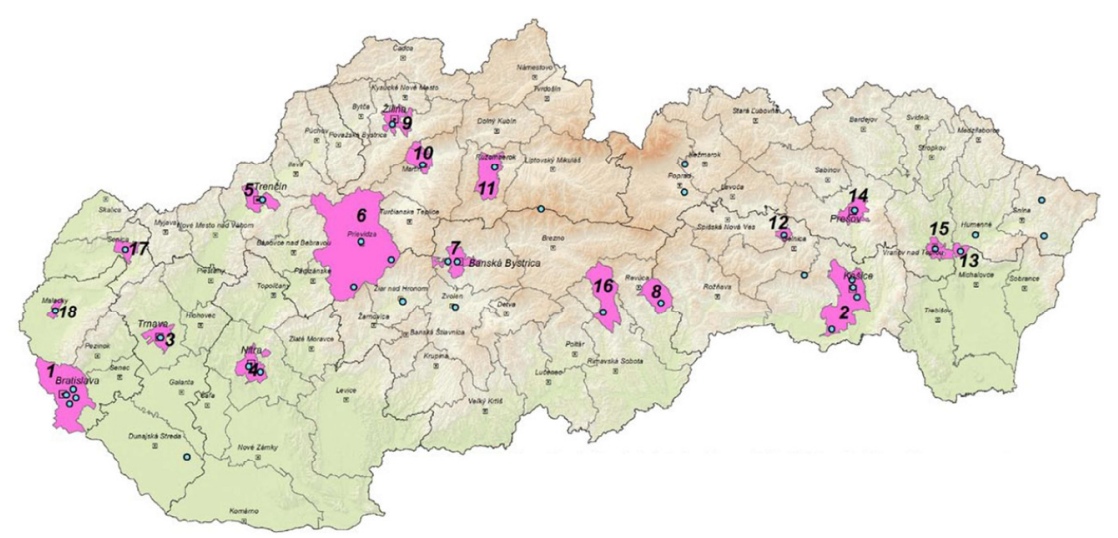

Fig. 2. Area around Vranov nad Topl'ou, Kučín, Nižný Hrabovec [2]. 
This map shows mining areas of mineral resources. Deposits of mineral sources are distinguished into reserved deposits and non-reserved deposits and according to the mine yield they are distinguished into small, medium and large deposits, shown in Fig. 3. The map also represents areas with negative impact on environment and areas with old mine works [2], [7].

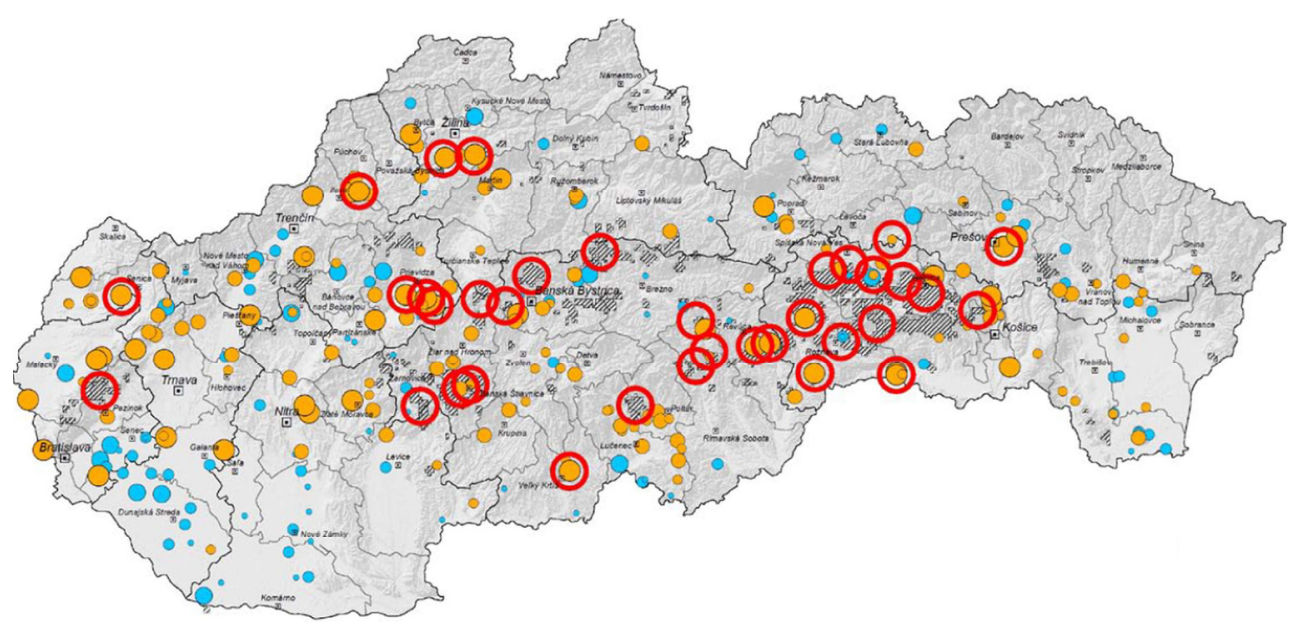

Fig. 3. Market area: without any risk locality from the point of impact on environment (area without red circle) [2].

The defined mining region is one of the areas with a moderate environmental burden. Defined mining region represents medium reserved deposits and medium non-reserved deposits without any risk localities from the point of impact on environment [2].

The map was created by spatial analysis of analytical maps of selected environmental characteristics according to structure of environment components and risk factors. It presents the basic differentiation of the Slovak Republic territory from the point of complex (cross-sectional) status of environment, shown in Fig. 4 [2], [3], [6].

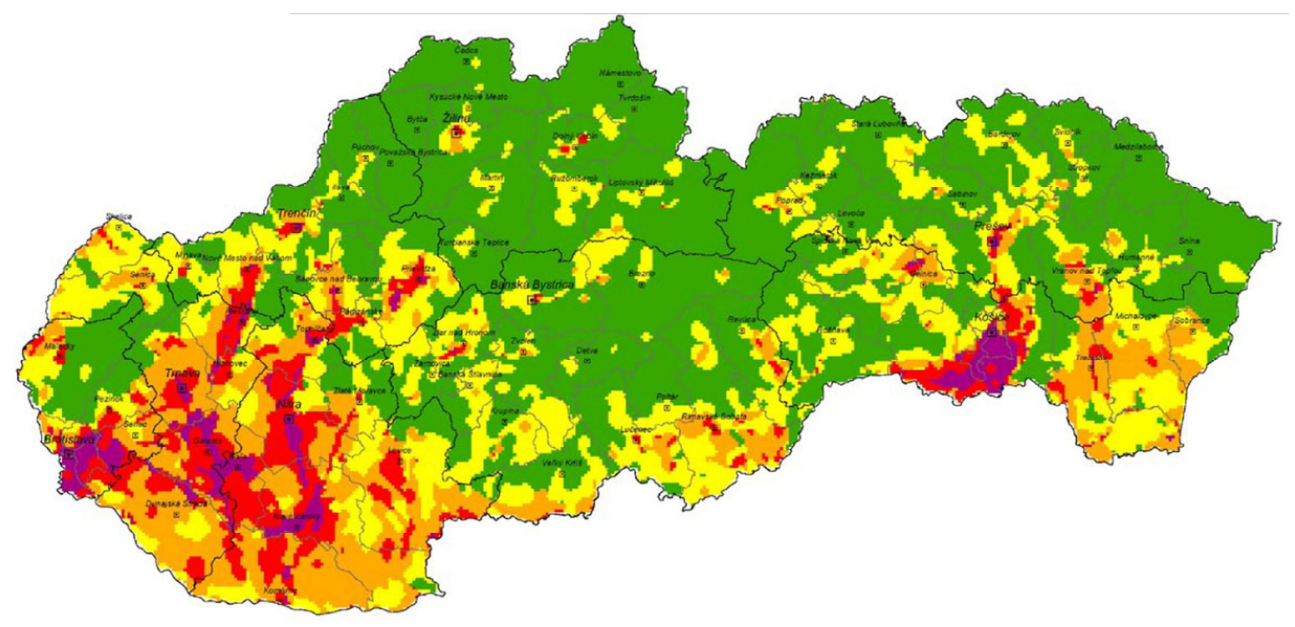

Fig. 4. Market area : Yellow - satisfactory environment, orange - environment moderately disturbed, red - disturbed environment [2]. 
The mining region is an area with a predominantly slightly disturbed environment (environment moderately disturbed). In the case of this region, it is mainly about air pollution (increased / high dustiness) [2], [8].

\section{Results and Discussion}

Environmental load is a territory pollution due to human activity. It presents serious risk on human health or rock environment, groundwater or surface waters and soils. The map shows localities with environmental loads and localities with environmental loads with restoration/recultivation in progress, shown in Fig. 5. There is also determined activity as originator of environmental load with expression of its risk category [2], [4].

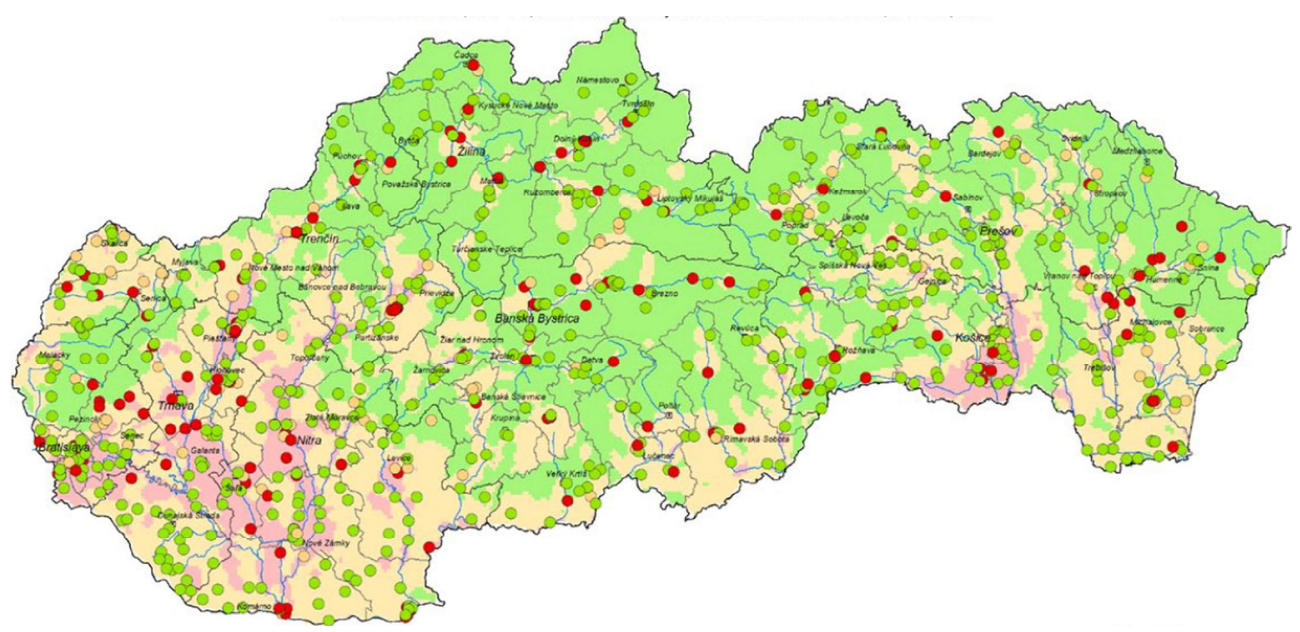

Fig. 5. Market area : The mining region include only 1 quarry with environmental load without restoration/recultivation in progress (red point), 1 point with environmental load with restoration/recultivation in progress (orange point), 1 point with environmental load restoration/recultivation (green point) [2], [3].

The territory of the whole of Slovakia is divided into smaller regions according to the environmental quality of the area. The current situation is recorded on the basis of the survey, analysis and processing of environmental regionalization. However, the current situation needs to be corrected and in the future to ensure the sustainable development of the mining regions in Slovakia. The Slovak Environmental Agency thus created current targets by 2025 and 2050, based on the current situation [2], [5].The mining region of the Vranov nad Topl'ou district includes, according to the degree of environmental quality, the territory with moderately disturbed environment and zone with disturbed environment. By 2025 , the environmental quality of this region will not be affected significantly (compared to today's environmental status), shown in Fig. 6. Significant changes in the environmental quality of the selected region are, according to the analysis, planned until 2050 shown in Fig. 7 [2], [4], [9]. 


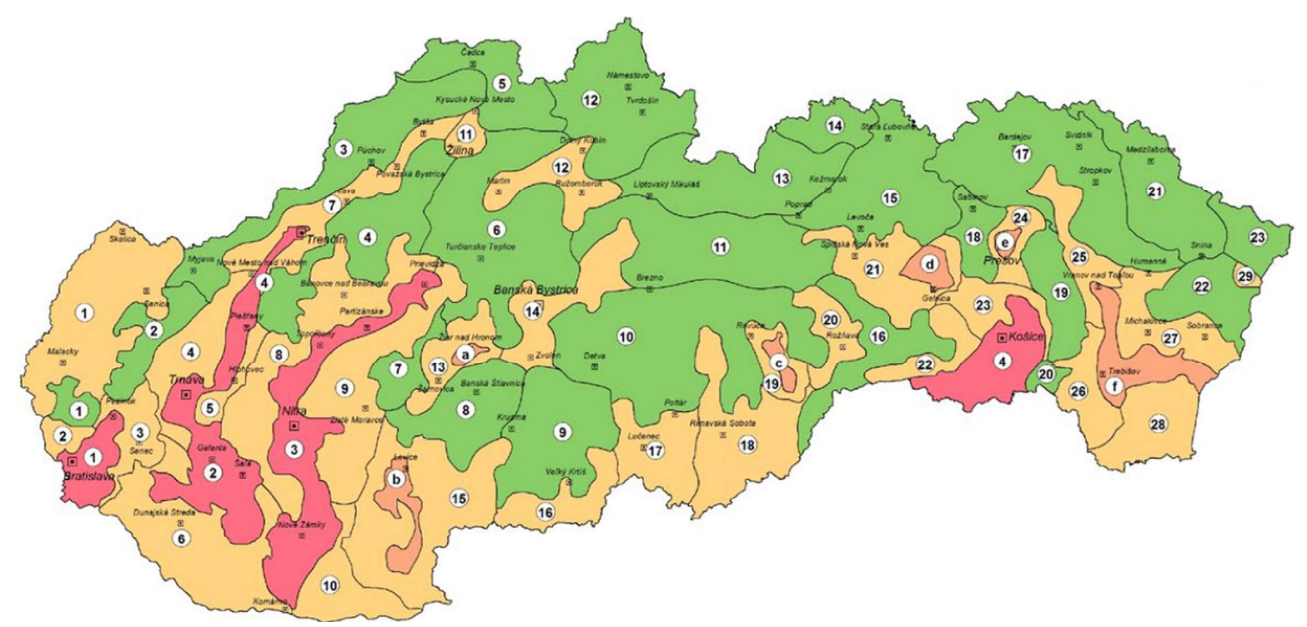

Fig. 6. Target to year 2025 : Market area : 25 - moderately disturbed environment and zone $\mathrm{f}$ - zone with disturbed environment [2].

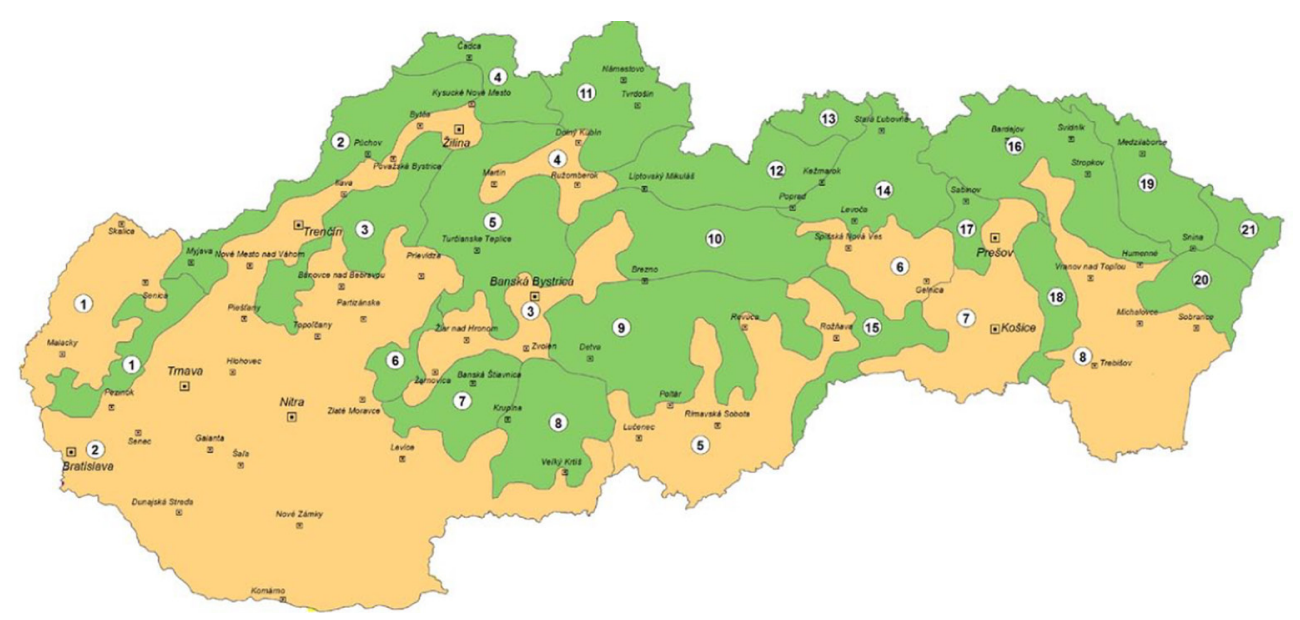

Fig. 7. Target to year 2050 : Market area - only areas without disturbed environment [2].

\section{Conclusion}

Zeolite extraction in Slovakia in the Vranov nad Topl'ou district is currently in constant operation. According to the statistics, Slovakia is third in the world in the mining and exporting of this raw material. In the mining region, the zeolite is mined by three mining companies (SLOVZEOLIT s.r.o., VSK PRO-ZEO s.r.o., ZEOCEM, a.s.) at all quarries (Kučín, Nižný Hrabovec, Majerovce, Pusté Čemerné). That is why attention is paid not only to mining, but also to the mining of the surrounding countryside. Zeolite-based companies in the region adhere to the directives needed to maintain the countryside and minimize environmental burdens. The status of the environmental burden on the surrounding country is monitored and, by 2050, will entail a significant improvement in the load and pollution of the landscape around the quarries. 


\section{References}

1. P. Baláž, D. Kúšik, Slovak minerals yearbook (TUKE, Kosice, 2016)

2. J. Klinda, T. Mičík, M. Némethová, M. Slámková, Environmental regionalization of the Slovak republic, (TUKE, Kosice, 2016)

3. M. Taušová, K. Čulková, S. Khouri, M. Cehlár, CEFE, 2017, 782-789 (2017)

4. Š. Markulik, M. Cehlár, R. Kozel, Acta Montanistica Slovaca, 23, 1 (2018)

5. M. Cehlár, J. Janočko, Z. Šimková, T. Pavlik, E3S Web of Conferences, 15, 01019 (2017)

6. M. Cehlár, J. Janočko, Odborný seminár SZVK, 19, 1-91 (2017)

7. M. Drevková, M. Vasilková Kmecová, S. Drevko, L. Gabániová, K. Šándorová, M. Kal'avský, D. Matisková, D. Tudoš, Management of Manufacturing Systems (TUKE, Kosice, 2017)

8. R. Lacko, Z. Hajduová, H. Pavolová, Acta Montanistica Slovaca, 22, 136-145 (2017)

9. P. Rybár, C. Drebenstedt, M. Molokáč, L. Hvizdák, L. Štrba, Acta Montanistica Slovaca, 20, 242-250 (2015) 